\title{
$\mathrm{C}$ 형 간염의 역학
}

서울대학교 의과대학 분당서울대학교병원 내과

정 숙 향

\section{Epidemiology of Hepatitis C Virus Infection in Korea}

\author{
Sook-Hyang Jeong \\ Department of Internal Medicine, Seoul National University Bundang Hospital, Seoul National University College of Medicine, \\ Seongnam, Korea
}

The anti-hepatitis C virus (HCV) prevalence in South Korean adults is estimated to be $0.8 \%$, suggesting that at least 290,000 people are HCV infected. HCV positivity increases with age and is slightly more prevalent in women than men. Among patients with chronic HCV infection, intravenous drug users comprise $<10 \%$, which is a distinct epidemiological feature of Western data. HCV genotype is a critical factor determining treatment regimen and duration. The major HCV genotypes in Korea are genotypes 1 (mostly genotype $1 \mathrm{~b}$ ) and 2. A peculiar intra-national geographic difference in anti-HCV prevalence was seen, as higher prevalence was found in southern coastal areas, such as Busan and Jeonnam. This geographic difference in exposure to risk factors for HCV infection suggests that active recognition and treatment is a priority in the Jeolla area, and that active prevention is an urgent issue in Busan. Considering the low recognition of $\mathrm{HCV}$ disease and the high cure rate using current antiviral therapy, the inclusion of a HCV screening test in the national health check examination program for people 40 years of age should be considered. Further studies on the HCV disease burden are warranted in this direct acting antiviral era. (Korean J Med 2015;88:630-634)

Keywords: Hepatitis C virus; Genotype; Liver cirrhosis; Carcinoma, Hepatocellular; Korea

\section{서 론}

1989년 C형 간염바이러스(hepatitis C virus, HCV)가 수혈 후 간염의 주된 원인으로 처음 발견된 이후[1] 전 세계적으로 $\mathrm{HCV}$ 는 만성간염, 간경변증 및 간세포암종에 의한 간질환 사 망률 및 간이식의 주요 원인으로 대두되었다[2]. 수혈 혈액에 대한 $\mathrm{HCV}$ 선별검사가 시행됨으로써 주요 감염원이 차단되
었지만 마약남용이나 관혈적 시술을 통한 $\mathrm{HCV}$ 감염은 여전 히 발생하고 있으며 아직 $\mathrm{HCV}$ 를 효과적으로 예방할 수 있 는 백신은 없다[3]. HCV는 우리나라 간경변증 및 간암 환자 의 약 $10-15 \%$ 의 원인으로, B형 간염바이러스 다음으로 중요 한 원인 인자이다[4,5].

$\mathrm{HCV}$ 감염의 치료제로 1990 년대 인터페론 단독요법이 시 도되었으나 불과 $10 \%$ 의 치료성공률을 보이는 난치병이었다.

Correspondence to Sook-Hyang Jeong, M.D., Ph.D.

Department of Internal Medicine, Seoul National University Bundang Hospital, Seoul National University College of Medicine, 82 Gumi-ro 173beon-gil, Bundang-gu, Seongnam 463-707, Korea

Tel: +82-31-787-7034, Fax: +82-31-787-4052, E-mail: jsh@snubh.org

Copyright (c) 2015 The Korean Association of Internal Medicine

This is an Open Access article distributed under the terms of the Creative Commons Attribution Non-Commercial License (http://creativecommons.org/licenses/by-nc/3.0/) which permits unrestricted noncommercial use, distribution, and reproduction in any medium, provided the original work is properly cited. 
2000년대 들어 페그인터페론 알파와 리바비린의 병합요법으 로 약 $50 \%$ 의 치료성공률로 향상되었지만 약제 부작용이 심하 여 실제 치료에 어려움이 많았다. 그러나 최근 direct antiviral agent (DAA)의 성공적인 개발로 거의 부작용 없는 경구약제 들을 3-6개월 복용하면 약 80-90\%의 치료성공률을 얻게 되 었다[6]. 이는 $\mathrm{HCV}$ 가 처음 발견된 후 25년 만에 $\mathrm{HCV}$ 를 박멸 할 수 있는 치료제를 개발함으로써 괄목할 만한 현대 의학의 승전보라 할 수 있다. 그러나 현재 DAA 약제들은 매우 고가 의 비용이 소요되어 많은 환자들에게 실제적 치료의 장벽이 되고 있는 실정이다[7]. 이 논고에서는 세계적인 $\mathrm{HCV}$ 역학 양상과 함께 우리나라 $\mathrm{HCV}$ 감염의 역학을 기술하여 $\mathrm{HCV}$ 예 방 및 치료 전략을 수립하는 데 도움이 되고자 한다.

\section{본 론}

\section{세계적인 HCV 역학}

\section{Anti-HCV 유병률 및 지역분포}

2000 년 이후 세계 87 개국에서 보고된 각 국가 인구의 HCV 항체 $(\mathrm{anti}-\mathrm{HCV})$ 유병률을 분석한 최근 연구에서 세계적인 $\mathrm{HCV}$ 항체 유병률은 1.6\% (95\% 신뢰구간, 1.3-2.1\%)이고, 이를 2013 년 유엔인구통계를 기준으로 추산하면 HCV 감염 인구수는 약 1 억 1,500만 명(95\% 신뢰구간, 9,200만 명-1억 4,900백만 명)이다. 이들 anti-HCV 양성자 중에 자연적 혹은 치료에 의 해 회복된 사람들을 제외하고 현재 $\mathrm{HCV}$ 증식이 혈중에서 검 출되는 사람이 $70 \%$ 를 차지하여 세계인구의 $1.1 \%$, 약 8,000 만 명이 치료의 대상이 되는 만성 $\mathrm{C}$ 형 간염환자로 추산된다. 감 염자의 $90 \%$ 는 성인이며 나머지 $10 \%$ 가 소아이다[8].

지역별 anti-HCV 유병률을 살펴보면 아시아에서는 우즈베 키스탄(11.3\%), 몽골(10.8\%), 파키스탄(6.7\%), 대만(4.4\%)이 높 고, 일본 $(1.5 \%)$, 중국 $(1.3 \%)$, 인도 $(0.8 \%)$, 호주 $(1.7 \%)$ 는 낮은 편 이다. 유럽에서는 러시아 $(4.1 \%)$ 및 동유럽에서 높고, 아프리 카 지역의 이집트(14.7\%), 카메룬(11.6\%), 가봉(11.2\%) 등도 매 우 높은 $\mathrm{HCV}$ 유병지역이다. 북미는 1.1-1.3\%, 남미는 $1.4-1.6 \%$, 그리고 서유럽은 $1-2 \%$ 내외의 유병률을 보고하고 있다[8].

\section{$\mathrm{HCV}$ 유전자형 분포}

$\mathrm{HCV}$ 는 염기서열의 변이에 따라 일반적으로 6개의 유전자 형(1형-6형)으로 구분된다. HCV 유전자형이 임상적으로 중요 한 이유는 항바이러스 치료의 약제나 치료기간을 결정하는 가장 주요 인자이기 때문이다. $\mathrm{HCV}$ 의 항바이러스 치료의 목 표는 지속바이러스반응(sustained virologic response, SVR)에
도달하는 것이고, SVR은 치료종료 후 24주에 혈중 HCV RNA 가 검출되지 않는 상태로 정의하며 이는 실제적 완치를 의미 한다[9]. 페그인터페론 알파와 리바비린 병합치료 시에 HCV 유전자형 1, 4형은 48주를 치료하여도 SVR이 40-60\%에 불 과하지만 $\mathrm{HCV}$ 유전자형 2, 3형은 24주만 치료하여도 SVR 도달률이 $80 \%$ 에 달한다. 최근 개발된 치료제 $\mathrm{DAA}$ 의 경우 $\mathrm{HCV}$ 유전자형 1 형 중에서도 $1 \mathrm{~b}$ 형인지 $1 \mathrm{a}$ 형인지에 따라 권 고되는 치료약제가 다르다[10]. 세계적인 $\mathrm{HCV}$ 유전자형 분 포를 보면 유전자형 1형이 가장 흔하여 $46 \%$ 를 차지하고, 유 전자형 3형이 $22 \%$, 유전자형 2,4 형이 각각 $13 \%$ 를 차지한다 [8]. 세계 지역별로 $\mathrm{HCV}$ 유전자형 분포는 차이가 많이 나는 데 북미, 남미나 유럽은 유전자형 1형이 53-71\%를 차지하지 만, 유전자형 3형은 동남아시아에 흔하고 유전자형 4형은 중 동지역, 이집트, 중앙아프리카에서, 유전자형 5형은 남아프리 카에서, 유전자형 6형은 홍콩, 마카오, 베트남에서 주로 발견 된다[11]. 또 최근 보고된 메타분석 결과에 의하면 $\mathrm{HCV}$ 유전 자형 $1 \mathrm{~b}$ 형은 다른 유전자형에 비해 1.78 배 간암발생 위험을 높인다고 보고되었다[12].

\section{$\mathrm{HCV}$ 감염의 위험인자}

과거에 $\mathrm{HCV}$ 감염은 주로 수혈에 의한 경우가 많았으나 1992년부터 수혈혈액에 대한 HCV 선별검사가 시행되고 전 반적 의료시술의 위생상태가 향상되면서 이로 인한 $\mathrm{HCV}$ 감 염은 점점 감소하고 있다. 사물에 묻어 있는 혈청내의 $\mathrm{HCV}$ 는 5일까지 감염력을 유지하는 안정성이 보고되어 있으므로 [13] 감염예방을 위해 혈액으로 오염된 의료도구나 사물의 표면을 깨끗이 소독하여 위생적으로 관리해야 한다. 최근의 북미나 유럽의 주된 감염경로는 마약주사남용인데 주사기나 주사침을 공유하거나 재사용하거나 마약을 혼합할 때 쓰는 도구 등을 혼용하는 행위를 통해 감염이 일어나며 마약남용 자의 절반 이상이 $\mathrm{HCV}$ 에 감염되어 있다. 이들은 $\mathrm{HCV}$ 의 주 된 감염원이 되고, 개별 환자에서 $\mathrm{HCV}$ 를 치료하여도 재감염 을 자주 일으키며, $\mathrm{HIV}, \mathrm{HBV}$ 와 같은 중복감염원으로도 작용 한다[6]. 남성간 성행위, 다수 성상대방이나 항문성교와 같은 위험성행위도 $\mathrm{HCV}$ 감염의 위험인자이며, 감옥수감자들도 $\mathrm{HCV}$ 감염에 높은 위험률을 가지고 있다[14]. 산모로부터 신 생아에게로 모자감염률은 $4 \%$ 로 보고되는데[9] 항바이러스 치 료제의 개발과 함께 점점 가임연령의 감염자들이 임신 전에 치료를 하고자 하므로 이들도 $\mathrm{HCV}$ 선별검사를 필요로 하는 군으로 대두되고 있다. 


\section{우리나라 HCV 역학}

\section{국내 HCV 항체 유병률 및 지역분포}

아직 우리나라 인구를 잘 대표하는 $\mathrm{HCV}$ 유병률은 알려져 있지 않다. 2009년 국내 29개 검진센터에서 20세 이상 성인 검진자 291,314명을 대상으로 연령, 성별, 지역을 당시 인구 로 보정한 $\mathrm{HCV}$ 항체 유병률은 $0.78 \%$ 였고, 이로써 우리나라 성인 $\mathrm{HCV}$ 감염자가 약 29만 명으로 추산할 수 있지만 대상 이 검진자이므로 일반 인구를 대표하지 못하는 한계가 있다 [15]. 우리나라에서 HCV 항체 유병률은 남자 $(0.75 \%)$ 보다 여 자 $(0.83 \%)$ 에서 더 높았고, 연령에 따라 증가하는 경향을 보 였다(20-29세 0.34\%, 30-39세 0.41\%, 40-49세 0.60\%, 50-59세 $0.80 \%, 60-69$ 세 $1.53 \%, 70$ 세 이상 $2.31 \%$ ) (Fig. 1). 또한, 지역 에 따라 $\mathrm{HCV}$ 항체 양성률이 유의한 차이를 보여 서울과 경 기도를 포함한 대부분의 지역에서는 $0.50-1.20 \%$ 였으나, 부산 과 전남 지역의 경우에는 각각 $1.53 \%, 2.07 \%$ 로 가장 항체 유 병률이 높았다(Fig. 2). 이 연구에서 anti-HCV 양성자 1,718명 중 478 명 $(28 \%)$ 만이 HCV RNA 검사를 시행 받았는데 이런 사 실은 $\mathrm{C}$ 형 간염의 진단이 적절히 이루어지지 않을 가능성을 제시한다. 그리고 상기 478 명 중에서 268명 $(56 \%)$ 이 HCV RNA 양성소견을 보였고, 148 명이 항바이러스 치료를 과거에 받았 거나 2009년 이후 받았다[15].

2005-2009년간 국내 헌혈자 11,064,532명에서 3세대 enzymelinked immunosorbent assay법을 이용한 HCV 항체 양성률은 $0.16 \%, \mathrm{HCV}$ RNA 양성률은 10 만 명의 헌혈자 중 8.4 명 $(0.0084 \%)$ 이었는데, 헌혈자 $81 \%$ 가 10 대와 20 대의 젊은 연령이고 건강 한 사람들이 헌혈을 하기 때문에 헌혈자에서 $\mathrm{HCV}$ 유병률은

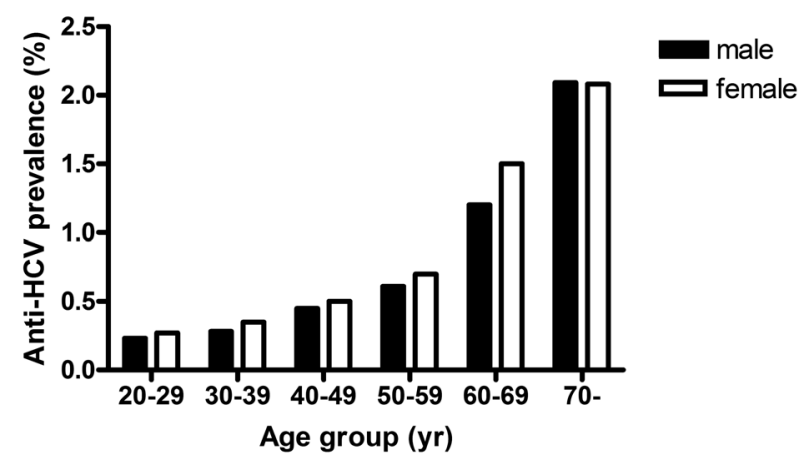

Figure 1. Age and sex-specific prevalence of anti-hepatitis C virus (HCV) in Korea, 2009 ( $n=291,314$ health check examinees). Anti-HCV prevalence in Korean adult health check examinees was $0.8 \%$, suggesting that at least 290,000 people are $\mathrm{HCV}$ infected. HCV positivity increases with age and is slightly more prevalent in women than men.
매우 낮았다[16]. 우리나라에서는 2005년 2월부터 헌혈혈액 선별검사에 HCV에 대한 핵산검사법(nucleic acid test)을 시 행하므로 수혈을 통한 $\mathrm{HCV}$ 감염위험도는 더 이상 없다고 볼 수 있다(2009/2010년의 경우 1/2,984,415건) [17]. 국내 산 모들에서 $\mathrm{HCV}$ 항체유병률은 $0.4 \%$ 정도이며, 소아에서 유병 률은 1996년 $0.8 \%$ 로 보고된 이후 더 이상의 보고가 없는 실 정이다[9].

국내 정맥주사 약물남용자에서 $\mathrm{HCV}$ 항체 양성률은 48-79\% 로 보고되었고, 혈액투석환자들에서는 6-15\% (2000년 이전 보 고), HIV 감염자에서는 5-6\% (2013년), 혈우병환자들에서는 $20 \%$ (2012년)의 HCV 항체양성률이 보고되었다[9].

현재 대한간학회 진료가이드라인에 따르면 우리나라에서 anti-HCV 선별검사 대상은 $\mathrm{HCV}$ 감염의 고위험군에 해당하 는 사람들로 수혈혈액 선별검사 전에 수혈받은 사람이나 마 약남용자, 혈액투석을 받거나 HIV 감염자, 혈우병환자 및 $\mathrm{HCV}$ 에 감염된 산모의 자녀 및 환자의 성상대방, 그리고 감 염환자의 혈액 및 체액에 노출된 의료진 등을 포함한다[9]. 그러나 C형 간염에 대한 일반국민의 인지도가 낮고 고위험 군을 대상으로 하는 선별검사가 효과적이지 않음이 우리나 라를 포함하여 이미 여러 나라에서 확인되었다. 미국에서는

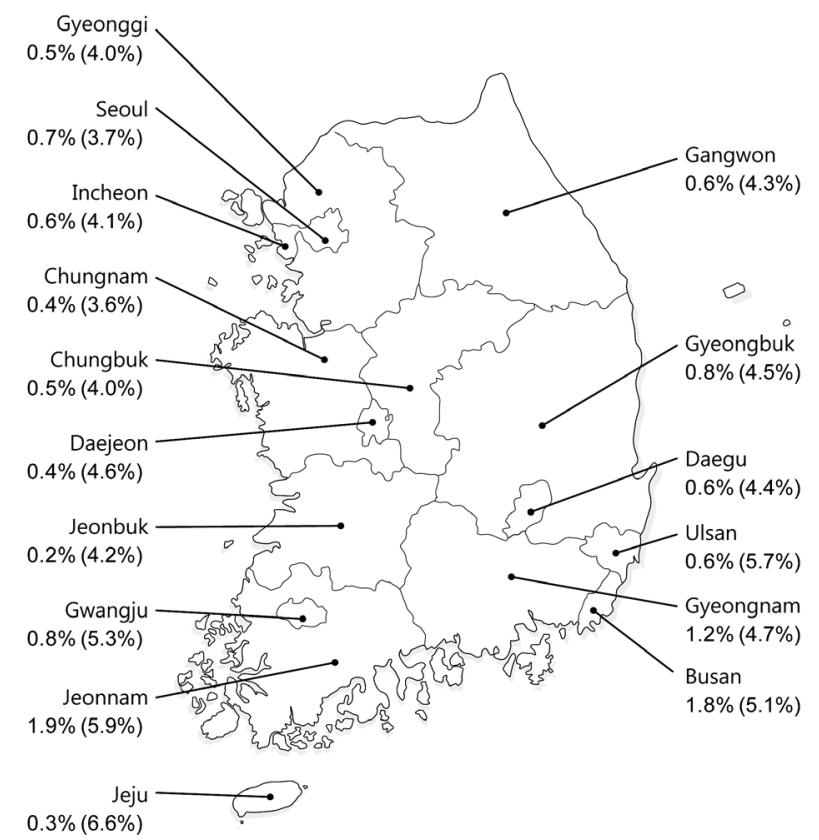

Figure 2. Age and sex-adjusted anti-hepatitis $\mathrm{C}$ virus (HCV) seroprevalence in different areas of Korea $(n=291,314$ health check examinees). A peculiar intra-national geographic difference in anti-HCV prevalence was seen, as higher prevalence was observed in southern coastal areas, such as Busan and Jeonnam. 
유병률이 높은 출생코호트를 대상으로 일생에 한 번 모든 인구에게 anti-HCV 선별검사를 권고하고 있다[18]. 우리나라 에서도 40 세에 시행하는 생애전환기 국가검진사업 검사항목 에 $\mathrm{HCV}$ 항체검사를 포함할 것을 고려해야 한다.

\section{HCV 유전자형 분포}

우리나라에서 흔한 $\mathrm{HCV}$ 유전자형은 $1 \mathrm{~b}$ 형(45-59\%)과 2a형 (26-51\%)이고 기타 $1 \mathrm{a}$ 형, $2 \mathrm{~b}$ 형, 3형, 4형, 6형 등이 $1 \%$ 미만으 로 보고되었다. 유전자형 1 형 중에는 $1 \mathrm{~b}$ 형이 $85 \%$ 이상을 차 지하고 1a형은 $10 \%$ 미만이다[19]. 우리나라 C형 간염환자 823명을 대상으로 $\mathrm{HCV}$ 유전자형이 $\mathrm{HCC}$ 발생에 미치는 영 향을 알아본 연구에서 $\mathrm{HCV}$ 유전자형 $1 \mathrm{~b}$ 형은 간암발생 위험 의 독립인자가 아니었다[20].

\section{$\mathrm{HCV}$ 감염위험 인자 및 환자군의 임상적 특징}

2007년부터 2011년 사이 국내 5개 대학병원에서 전향적으 로 진행된 1,173 명의 $\mathrm{HCV}$ 환자군과 534 명의 대조군과의 비 교연구에서 만성 $\mathrm{HCV}$ 감염 환자군의 평균나이는 55세, 남녀 비는 0.9 , 진단구분에서 만성간염이 $72 \%$, 간경변증이 $17 \%$, 간 암이 $11 \%$ 를 차지하였다. B형 간염과 중복감염률이 $5 \%$ 였으 며 $\mathrm{HCV}$ 유전자형 1형이 $53 \%, 2$ 형이 $45 \%, 3,4,6$ 형이 $2 \%$ 였고, 유전자형 $1 \mathrm{~b}$ 형에서 간경변증 및 간암환자군의 비율(29.4\%)이 non- $1 \mathrm{~b}$ 형(22.5\%)에서보다 높았으나 간암의 비율은 차이가 없 었다. 환자군에서 과거수혈병력은 $19 \%$ 에서, 정맥주사 약물남 용 병력은 $5 \%$ 에서 관찰되었는데 약물남용자들은 남자가 많 고 나이가 40 대가 많았다. 이 연구에서는 정맥주사 약물남용, 주사바늘 찔림, 1995년 이전 수혈, 문신, 나이가 국내 HCV 감 염의 독립적인 위험요인이었다[21].

국내 $\mathrm{HCV}$ 항체 유병률이 부산, 경남 및 전남지역이 타지 역에 비해 유의하게 높은 특징을 보이는데, 호남권, 부산지역 의 환자군을 대상으로 수도권 환자군과 위험인자를 비교분 석한 연구에서 호남지역 환자들은 나이가 많고 간암환자가 많은 반면 감염위험인자 노출력은 수도권에 비해 전반적으 로 낮았다. 반면 부산환자군은 수도권 환자들에 비해 관혈적 시술이나 다수 성상대방 같은 위험인자 노출력이 유의하게 높았다[22]. 따라서 호남권 환자들은 현재로서는 알 수 없는 오랜 과거에 이미 HCV에 감염된 고령의 감염코호트가 존재 하고 질환도 이미 진행한 경우가 많아 진단에 적극적으로 나 서 치료에 집중할 필요가 높다. 반면 부산권 환자들은 교정 가능한 감염요인들을 많이 가지고 있으므로 치료와 함께 적 극적인 예방전략이 필요할 것으로 생각된다.

만성 C형 간염 환자들 중 $15-56 \%$ 는 20-25년의 기간을 거
치면서 간경변증으로 진행하게 된다. 국내 단일기관을 방문 한 1,137 명의 만성 $\mathrm{HCV}$ 감염자들을 평균 55.2 개월 동안 추 적 관찰하였을 때 간암, 자발세균복막염, 정맥류출혈, 간성뇌 증, 간질환 관련 사망 등의 질병의 진행을 보인 경우가 $14.2 \%$ 로 1년에 2.0-2.5\%였다. 전체 1,137명 중 490명(43.0\%)이 항바 이러스 치료를 받았으며 항바이러스 치료 후 5 년 누적 질병 의 진행률은 SVR을 보인 경우(3.7\%) SVR을 보이지 않은 경 우보다(13.0\%) 유의하게 낮았다[23]. 따라서 C형 간염은 간 경변증이나 간암으로 진행하기 전에 진단하여 항바이러스 치료를 하면 완치가 가능하므로 우리나라 인구와 환자들의 역학적 특성을 이해하고 조기 진단과 적극적 치료로 $\mathrm{HCV}$ 로 인한 질병부담을 획기적으로 줄일 수 있기를 기대한다.

\section{결 론}

우리나라 성인에서 HCV 항체 유병률은 $0.8 \%$ 로 약 29 만 명 의 감염자가 있을 것으로 추산되는데 나이가 증가할수록 유 병률이 높고 여성에서 유병률( $0.83 \%)$ 이 남성 $(0.78 \%)$ 보다 약 간 높다. 한편 만성 $\mathrm{C}$ 형 간염 환자군에서 마약남용자가 전체 환자군의 $10 \%$ 미만을 차지하여 서구의 역학과는 상이한 특 징을 보이고 있다. 국내 환자군의 $\mathrm{HCV}$ 유전자형은 1 형과 2 형이 각각 절반을 차지하며 1 형 중에는 $1 \mathrm{~b}$ 형이 대부분이므로 항바이러스 치료의 비용적정성 등을 예상하는 데 중요하게 고려되어야 한다. 부산, 경남지역 및 호남권의 유병률이 국내 다른 지역보다 유의하게 높은데 호남권은 원인을 알 수 없는 과거 감염으로 현재 환자군의 나이가 많고 간질환의 중증도 가 심한 경향이 있으므로 진단과 치료가 우선적으로 시행되 어야 하고, 부산지역은 관혈적 시술 및 정맥주사 남용과 같은 위험인자를 차단하는 예방전략의 수립과 실행이 시급하다. 아 직 국내 인구를 대표할 만한 역학 연구가 부족하고 일반인과 의료진에서 $\mathrm{C}$ 형 간염에 대한 인지도가 낮으므로 진단이 늦 어져 질병부담을 증가시키는 점을 고려하여 40 세 이상 인구 에서 생애 한 번 선별검사 시행을 제안하며, 질병의 비용효 과 연구에 근거한 치료전략이 수립을 위한 연구가 필요하다.

중심 단어: $\mathrm{C}$ 형 간염항체; 유전자형; 간경변증; 간세포암 종; 한국

\section{REFERENCES}

1. Choo QL, Kuo G, Weiner AJ, Overby LR, Bradley DW, Houghton M. Isolation of a cDNA clone derived from a 
blood-borne non-A, non-B viral hepatitis genome. Science 1989;244:359-362.

2. Hajarizadeh B, Grebely J, Dore GJ. Epidemiology and natural history of HCV infection. Nat Rev Gastroenterol Hepatol 2013;10:553-562.

3. Honegger JR, Zhou Y, Walker CM. Will there be a vaccine to prevent HCV infection? Semin Liver Dis 2014;34:79-88.

4. Lee SS, Jeong SH, Jang ES, et al. A prospective cohort study on the outcomes of hepatitis C virus-related cirrhosis in South Korea. J Gastroenterol Hepatol 2015 Mar 16 [Epub ahead of print].

5. Lee SS, Byoun YS, Jeong SH, et al. Type and cause of liver disease in Korea: single-center experience, 2005-2010. Clin Mol Hepatol 2012;18:309-315.

6. Welsch C, Jesudian A, Zeuzem S, Jacobson I. New directacting antiviral agents for the treatment of hepatitis $\mathrm{C}$ virus infection and perspectives. Gut 2012;61 Suppl 1:i36-46.

7. Myers RP, Krajden M, Bilodeau M, et al. Burden of disease and cost of chronic hepatitis $\mathrm{C}$ infection in Canada. Can $\mathrm{J}$ Gastroenterol Hepatol 2014;28:243-250.

8. Gower E, Estes C, Blach S, Razavi-Shearer K, Razavi H. Global epidemiology and genotype distribution of the hepatitis C virus infection. J Hepatol 2014;61(1 Suppl):S45-57.

9. Korean Association for the Study of the Liver (KASL). KASL clinical practice guidelines: management of hepatitis C. Clin Mol Hepatol 2014;20:89-136.

10. Kohli A, Shaffer A, Sherman A, Kottilil S. Treatment of hepatitis C: a systematic review. JAMA 2014;312:631-640.

11. Messina JP, Humphreys I, Flaxman A, et al. Global distribution and prevalence of hepatitis $\mathrm{C}$ virus genotypes. Hepatology 2015;61:77-87.

12. Raimondi S, Bruno S, Mondelli MU, Maisonneuve P. Hepatitis $\mathrm{C}$ virus genotype $1 \mathrm{~b}$ as a risk factor for hepatocellular carcinoma development: a meta-analysis. J Hepatol 2009;50:11421154.

13. Doerrbecker J, Friesland M, Ciesek S, et al. Inactivation and survival of hepatitis $\mathrm{C}$ virus on inanimate surfaces. J Infect Dis 2011;204:1830-1838.

14. Alter MJ. HCV routes of transmission: what goes around comes around. Semin Liver Dis 2011;31:340-346.

15. Kim do Y, Kim IH, Jeong SH, et al. A nationwide seroepidemiology of hepatitis $\mathrm{C}$ virus infection in South Korea. Liver Int 2013;33:586-594.

16. Oh DJ, Park YM, Seo YI, Lee JS, Lee JY. Prevalence of hepatitis $\mathrm{C}$ virus infections and distribution of hepatitis $\mathrm{C}$ virus genotypes among Korean blood donors. Ann Lab Med 2012; 32:210-215.

17. Kim MJ, Park Q, Min HK, Kim HO. Residual risk of transfusion-transmitted infection with human immunodeficiency virus, hepatitis $\mathrm{C}$ virus, and hepatitis $\mathrm{B}$ virus in Korea from 2000 through 2010. BMC Infect Dis 2012;12:160.

18. Asrani SK, Davis GL. Impact of birth cohort screening for hepatitis C. Curr Gastroenterol Rep 2014;16:381.

19. Seong MH, Kil H, Kim JY, et al. Clinical and epidemiological characteristics of Korean patients with hepatitis $\mathrm{C}$ virus genotype 6. Clin Mol Hepatol 2013;19:45-50.

20. Cho EJ, Jeong SH, Han BH, Lee SU, Yun BC, Park ET. Hepatitis $\mathrm{C}$ virus (HCV) genotypes and the influence of $\mathrm{HCV}$ subtype $1 \mathrm{~b}$ on the progression of chronic hepatitis $\mathrm{C}$ in Korea: a single center experience. Clin Mol Hepatol 2012;18:219224.

21. Seong MH, Kil H, Kim YS, et al. Clinical and epidemiological features of hepatitis $\mathrm{C}$ virus infection in South Korea: a prospective, multicenter cohort study. J Med Virol 2013;85:17241733.

22. Kim KA, Jeong SH, Jang ES, et al. Geographic differences in the epidemiological features of HCV infection in Korea. Clin Mol Hepatol 2014;20:361-367.

23. Sinn DH, Paik SW, Kang P, et al. Disease progression and the risk factor analysis for chronic hepatitis C. Liver Int 2008;28:1363-1369. 